\title{
Library use and academic achievement
}

\author{
K. de Jager \\ School of Librarianship, University of Cape Town, Private Bag, Rondebosch, 7700 Republic of Sout Africa \\ kdej@education.uct.ac.za
}

\begin{abstract}
Objective measures of the impact of library services are difficult and in view of some writers even impossible to obtain. As part of a major investigation into the support provided by the University of Cape Town Library Service for both the studying and research activities at the university, an investigation was launched to establish objectively whether any statistically significant association could be shown to exist between student academic performance and library use. Earlier investigations at institutions in Australia and the United States of America had indicated that such an association could by no means be assumed. If it could therefore be shown through matching of examination results and library borrowing records at the University of Cape Town, that students with the best academic performance used the most library materials and that those with low or failing grades used significantly fewer, it would be possible to demonstrate objectively the value of the library service.
\end{abstract}

Dit is besonder moeilik en volgens sommige skrywers selfs onmoontlik om objektiewe maatstawwe vir die impak van biblioteekdienste te verkry. As deel van 'n grootskaalse ondersoek na die diens wat deur die biblioteek aan die Universiteit Kaapstad gelewer word ter ondersteuning van navorsing- en onderrigaktiwiteite, is 'n projek geloods om objektief vas te stel of daar ' $n$ verband bestaan tussen studente se akademiese prestasie en hul biblioteekgebruik. Vroeëre ondersoeke in Australië en die Verenigde State van Amerika het aangedui dat so 'n verhouding nie as vanselfsprekend aanvaar kan word nie. Indien dus aangetoon kan word dat studente met die beste akademiese prestasie ook die meeste biblioteekmateriaal gebruik en dat diegene met swakker prestasies biblioteekmateriaal beduidend minder gebruik, sou dit moontlik wees om objektief die waarde van biblioteekgebruik uit te wys.

\section{Value of student library use}

In a study to assess objectively the extent and value of student library use, Mays (1986) noted that student opinion is not a reliable indicator of actual library use as reflected by borrowing activity. While the value of user opinions on library services cannot be discounted, user opinion alone might not be regarded as a sufficient indicator of the vale of the library services on offer. Overall, Mays noted that undergraduate students did not use their library very much and that library usage did not correlate very well with academic performance. Some years earlier, Knapp (1968:301) had expressed a contrary opinion that some correlation did exist between library borrowing and academic achievement. Barkey (1965:117) had found that while a correlation did exist between academic achievement and the number of books taken out by students in his investigation, students could also succeed quite satisfactorily without using the library at all.

In another Australian study investigating the link between library usage and academic performance, Hiscock (1986) did not find significant correlation between academic achievement and the extent to which both recommended readings and personally selected readings were used by students. In the light of these conflicting conclusions, it seemed important that objective measures of the effects of library use on user outputs should be sought to demonstrate that close relationships existed between the costs and benefits of library services on the one hand, and the teaching mission of the university on the other. ${ }^{1}$ Investigations into more subjective student evaluations of library services at the University of Cape Town (UCT) were discussed in an earlier publication (De Jager, 1991).
In an attempt, therefore, to establish objectively whether any statistically significant relationship between academic performance and library use could be shown to be present at UCT, an exploratory investigation was conducted. It was decided that students' final examination results and library loan records would be matched to see if any association could be discerned between the borrowing of either short loan or open stack materials on the one hand, and student achievement on the other hand.

\section{Research assumptions}

The research problems to be investigated were threefold. In the first place, it was assumed that students with the best academic scores would have used the most library materials and that students with low or failing grades would have used library materials to a significantly lesser degree. Secondly, it was assumed that since the Short Loan collection contained materials that were prescribed readings, most students would have used at least some of those and that the best students would have used significantly more open shelf materials for work beyond the basic requirements. It was therefore expected that differences between the high and low scorers would be significantly greater in the case of open shelf material, than for Short Loan material. Confirmation for this supposition was provided by Asheim (1959:14), who stated that students who performed better academically, read more non-prescribed material than the poorer students, who read very little of what was not specifically assigned.

In the third place, since 'course readers' consisting of 'packages' of photocopied readings are fairly commonly provided for first-year students at UCT, it was postulated that library use would be more positively associated with student 
achievement at third-year rather than at first-year level. As first-year students often have readings provided for them and rely primarily on the Short Loan collection for study purposes, it was assumed that first year students would have made less use of the open shelf collection than the third-year students and that the correlation between library use and achievement would be less significant for first year students. Support for this assumption was also provided by Lane (1966:278), who found that first-year students used nonreserved library books significantly less than senior students.

Finally, if library use could indeed be shown to correlate positively with academic performance, it would be possible to question Ford's statement (1990:6) that beneficial use of libraries cannot be measured by indirect means such as quantitative counting, but only directly, by asking or observing users. It is suggested that if students who could be shown to have used the library more, also perform better academically, measures of the extent of use might indeed also measure the benefit that students could obtain from library use.

\section{Methodology}

Class lists publishing final results are commonly posted on academic departmental notice boards at the end of each semester at UCT. These subject lists are arranged alphabetically and consist of student names, student numbers, and each final mark in the form of a percentage for each particular course. It was envisaged that a sample of student numbers would be selected on the basis of highest and lowest scores in a particular course and then match those student numbers with their library borrowing records. Student numbers only would be selected to preserve individual anonymity at all times.

The process of matching student numbers with library borrowers' records was possible, but an extremely cumbersome process according to the old circulation system which had not yet been replaced. Borrowing records reflected Short Loan and open stack issues separately, but each individual record had to be called up and printed out as a report. In view of the time required to select and print these reports and the fact that all student borrowing records were due to be erased from the computer memory at the end of December, a relatively small sample only could therefore be matched and correlated.

The most appropriate subject areas for such a preliminary investigation were considered to be subjects for which it was objectively known that library use was high and for which increased library use could reasonably be expected to improve performance. In addition, courses that would have required the use of the main Library and the Short Loan Centre, rather than any of the departmental libraries, had to be chosen, as these records were the only ones available from the computerized system. An earlier investigation (De Jager, 1994) had established that English, economics, history, engineering and sociology (in that order) were the subject areas for which heaviest library use had been documented in the previous year. Most of these subjects were also conveniently taught at
UCT as English 1, 2, and 3; History 1, 2, and 3. At third-year level, sociology comprised two mutually exclusive courses which could be combined into a single set of third-year results.

In choosing subject areas for the present study, it was decided to eliminate the subject 'English' as this seemed to be the area where library use would be most evident and high use expected even from poor students. The subject area indicating 'engineering', however, presented some difficulties. It seemed appropriate to match student numbers against achievement from at least one science subject.

Unfortunately this was impossible, as no single course such as Engineering 1 or Engineering 3 is taught at UCT. A wide range of courses from the different engineering departments, such as chemical, electrical, mechanical and civil engineering, all utilize engineering works from the library and it was doubted whether meaningful numbers could be obtained from a selection of engineering course results. It was therefore recognized that a limitation of this study would be that it only dealt with subjects from what could be broadly characterized as the social sciences and humanities.

In view of the fact that the library was able to match and process only limited student numbers with library use records, the decision was made to test larger samples from fewer subjects to increase the validity of the conclusions. Thus the remaining three subjects in which high use had been proved, economics, history and sociology, were selected.

To test whether first-year students made less use of library materials than third years, a single first-year course, History 1 , was chosen for investigation. The selected class lists provided a population of 808 student records: 228 from History 1, 115 from History 3, 298 from Economics 3 and 167 from the combined third-year Sociology group. From each class group 60 records were selected; 240 in all.

The selected 60 records consisted of the 20 highest scores in each class, the 20 lowest scores and also a cluster of 20 scores around the mid-point between the highest and lowest score to test whether average students had used library materials differently from the high and low scorers. The results were plotted to distinguish between the use of open shelf materials and materials from the Short Loan collection.

\section{Research findings}

The evidence produced a number of interesting findings. Simple mean scores for the three groupings (top, middle and lowest) in each subject suggested that a positive relationship between the use of open shelf books and academic achievement might indeed be present in the subjects of history, both at first-year and third-year levels, and sociology. In the case of economics, however, the situation was not clear.

As far as the use of Short Loan books was concerned, the picture was more confused. In both History 1 and History 3 , the top scorers had seemed to use the Short Loan collection to a significantly greater extent than the low scorers, but the middle achievers had used it slightly more than the top scorers. This finding was also evident in the case of 
sociology, but the distinctions were less clear-cut. As far as economics was concerned, the middle achievers had used the Short Loan collection least of all, with a little distinction between the top and lowest scorers. These results are illustrated in the Table 1.

A question whether course readers might have played a role in the borrowing activity of all these students was briefly investigated. Administrative assistants in all three departments concerned were contacted to find out whether compulsory course readers had been made available to the classes under investigation. When it was discovered that course readers had been provided in all instances, it was decided to disregard the influence that course readers may have had on borrowing activity for the purposes of this investigation.

\section{Discussion}

The above findings seemed to confirm the first assumption. A positive relationship between academic achievement and the use of open shelf library books was established in three of the four classes that were investigated. The best students in all subjects except economics had taken out notably more open shelf books than both the average and the poor students. This relationship was not confirmed in the use of Short Loan material, where average scorers had slightly more recorded loans than top scorers in all instances except economics.

A reason for this pattern of use of Short Loan material could be found in the fact that Short Loan material circulates for very short periods. Items for use in the library only may be charged out for periods of three hours (one hour for materials in very high demand), or for removal overnight. Hard working students who are not also high achievers may therefore need to use prescribed materials for longer periods than high

Table 1 Mean scores and numbers of loans

\begin{tabular}{lccc}
\hline Subject & $\begin{array}{c}\text { Mean exam } \\
\text { mark }\end{array}$ & $\begin{array}{c}\text { Mean book } \\
\text { loans }\end{array}$ & $\begin{array}{c}\text { Mean short } \\
\text { loans }\end{array}$ \\
\hline Top History 1 & 71.2 & 18.4 & 57.4 \\
Middle History 1 & 58.5 & 15.6 & 66.5 \\
Lowest History 1 & 47.5 & 2.2 & 43.4 \\
Top History 3 & 72.5 & 33.6 & 104.4 \\
Middle History 3 & 61 & 20.9 & 108.4 \\
Lowest History 3 & 50.8 & 13 & 74.9 \\
Top Sociology 3 & 69 & 31.5 & 54.8 \\
Middle Sociology 3 & 59.1 & 16.7 & 70.2 \\
Lowest Sociology 3 & 49.8 & 14.4 & 51.1 \\
Top Economics 3 & 72.4 & 5.4 & 49 \\
Middle Economics 3 & 62 & 6 & 41.6 \\
Lowest Economics 3 & 47.8 & 7.1 & 46.4 \\
\hline
\end{tabular}

achievers, who also read the materials, but might require briefer periods of exposure.

These results to some extent confirm findings by Self (1987), who investigated the relationship between student grades and 'reserve readings'. He found that users of the reserve collection tended to have higher grades than non-users, but that the relationship was a rather weak one and that use of the reserve collection was not a good predictor of an individual student's grade marks. Findings from the present investigation support Self's conclusion that use of the Short Loan collection is not a good predictor of achievement.

The assumption that greater library use would be more significantly associated with academic achievement at third rather than at first-year level, was not upheld. History 1, the only first-year subject investigated, showed a remarkably positive relationship between the use of open shelf materials and student achievement. As far as the Short Loan materials use in history was concerned, the evidence was less conclusive, but the same pattern observed in the first-year course was maintained in the third, although History 1 students had indeed read significantly less than students in History 3 . This point was also confirmed by another investigation which found that first-year students claimed to need fewer nonShort Loan materials than other students (Research Surveys, 1994).

\section{Further investigation}

Although the mean scores noted in Table 1 seemed to indicate that relationships existed between academic achievement and the borrowing of especially open shelf books, the significance of these relationships was not yet proved. Perusal of the raw data had shown large individual differences in borrowing behaviour. The scatter graph for History 3 in Figure 1, for example, indicates the extent to which the apparently obvious difference between bottom and top scorers and the amount of their borrowing, was confused by a-typical individual scores.

The standard errors of the differences between the mean open shelf and short loan circulation for the top, middle and lowest groupings in the various subjects were very large. It was therefore impossible to prove by calculation of the t-test, which is a standard statistical technique used for indicating the significance of the difference between means (Chase, 1967:148), that the differences indicated by the mean scores in Table 1 were indeed significant. Upon perusing the

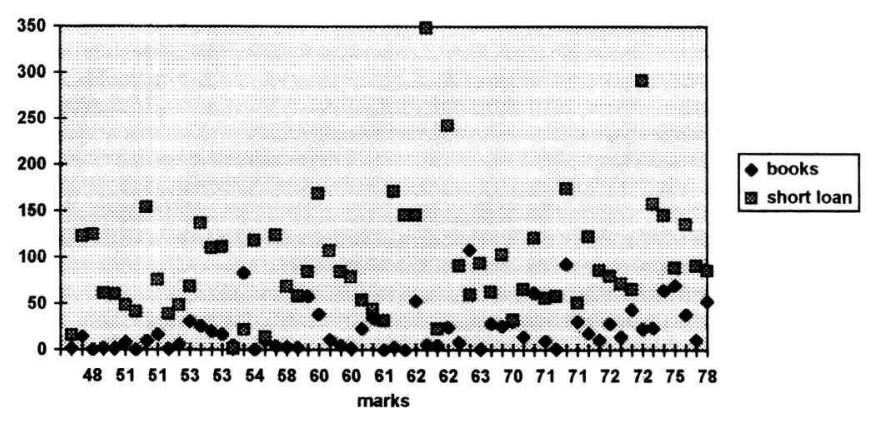

Figure 1 History 3: borrowing scatter 
distributions, however, it was evident that it should be possible to prove that significant differences existed at least between open shelf borrowing of the high and low scoring students in history and sociology. Further tests for proof of significant difference between two samples were therefore investigated.

One such a test, the 'Mann-Whitney Statistic', was specifically designed as 'a way of expressing in a single number a comparison between two samples' (Moses, 1986: 163). This technique consists of ranking two sets of data $x$ and $y$. Comparing the sums of the ranks ( $R x$ and $R y)$ of the two sets, one can derive the Mann-Whitney test statistic that

$$
U(x<y)=R_{y}-\frac{n(n+1)}{2}
$$

where $n$ is the number of samples in a set.

The significance of the observations can be found from precomputed tables, reproduced for example in Daniel (1978: 408-412), which provide calculated values of $U$ for significance levels between .001 and .10 .

The top and lowest sets only, of data for book and Short Loan circulation were compared in all cases. The procedure consisted of ranking the combined data and summing the ranks of the top set to yield $R_{y}$ and $U$. From the value of $U$ the significance level of the results could be read from the computed table in Daniel. Table 2 summarizes the results.

One could therefore state that significant differences could indeed be proved to exist between academic achievement and the borrowing of open shelf book material in the subjects of history and sociology. The assumption that significant correlation between the use of open shelf materials and achievement was less for first-year than for third-year students, was not upheld. In the case of history, the only subject for which this was tested, Table 2 shows that the significance level of difference between the top and lowest scores was the same. There was no difference in the extent to which top and low scorers in economics borrowed material from the library.

Additional investigation in the case of Economics 3 seemed to be required. Here were no positive correlations between the use of library materials and academic achievement. Further scrutiny of the loan activities of Economics 3 students, indicated that transactions had been slowest in this subject area. The identified Economics 3 students had taken out both

Table 2 Significance level of difference between top and lowest scores

\begin{tabular}{lll}
\hline Subject & Book loans & Short loans \\
\hline History 1 & p.001 & not significant \\
History 3 & p.001 & p.01 \\
Sociology 3 & p.05 & not significant \\
Economics 3 & not significant & not significant \\
\hline
\end{tabular}

Table 3 Number of loans by subject

\begin{tabular}{lccccc}
\hline & History 1 & History 3 & Sociology 3 & Economics 3 & Total \\
\hline Open shelves & 722 & 1346 & 1251 & 371 & 3690 \\
Short Loans & 3345 & 5752 & 3520 & 2744 & 15361 \\
\hline
\end{tabular}

the fewest open shelf materials and the fewest Short Loan materials, as illustrated by Table 3 .

It therefore seems evident that Economics 3 students had not made use of the library to the same extent as students of history or sociology. A previous study (De Jager, 1994) had, however, indicated particularly high incidence of loan activity in the economics subject area. This apparent contradiction may partly be explained by the fact that the Economics classes were considerably larger than any of the others for which high library use was recorded in the earlier study. For example, the Economics 1 class had 853 students as evidenced by the end-of-year results sheets, English 1 had 519, Sociology 1 had 454 and History 1 had 228. Many more students could therefore have been competing for books in the subject field of economics in the library.

Earlier investigations, such as that by Kramer and Kramer (1968:311), had also found remarkable variations in library use depending on the subject concerned. The Australian studies of Mays and Hiscock reported no, or very weak, correlation between library use and student performance. The absence of a relationship evidenced by these economics results therefore might also indicate that library use cannot be presumed to relate positively to academic achievement in all instances. This in turn suggested that it might be possible to measure the beneficial use of libraries, in certain subjects, by indirect means.

In this regard, Evans (1970:300) had noted that correlation and causation should never be equated. One cannot simply assume that attempts to increase library use will inevitably produce better academic results. It is still very difficult or perhaps impossible to prove whether books taken out of a library were actually read or understood by their borrowers. The evident relationships between academic performance and library use in history and sociology do however suggest that this relationship could be the subject of further investigation and an instrument in motivating students to read more library materials. It also needs to be established whether the lack of such correlation in economics is caused by library use that is not rewarded, or not encouraged, or whether other reasons might exist.

\section{Recommendations}

It is suggested that this investigation could be repeated over a much wider range of subjects and including the sciences, as it could provide one of the most concrete sets of evidence of the outcome and potential benefit of library use of students at university. At present the computerized library system at $\mathrm{UCT}$ is not able to provide this information on a routine basis, 
but once the new system is fully in place, the library could be able to provide teachers with concrete evidence of the extent to which it supports their activities. In cases where library use does not clearly correlate with academic achievement, consultation between librarians and academic staff could result in providing teachers with new tools with which to enhance the success of their educational activities.

\section{Note}

1. An urgent plea for the demonstrations of such relationships was expressed by Patrick W. Leonard in: This year is different: outcome assessment. Journal of academic librarianship, 18(4), 1992:231.

\section{References}

ASHEIM, L. 1959. A survey of recent research. In Price, J.M. ed. Reading for life: developing the college student's lifetime reading interest. Ann Arbor: University of Michigan Press.

BARKEY, P. 1965. Patterns of student use of a college library. College \& research libraries, 20(2):115-118.

CHASE, C.I. 1967. Elementary statistical procedures. New York: McGraw-Hill.

DANIEL, W.W. 1978. Applied nonparametric statistics. Boston, Mass.: Houghton Mifflin. Quantiles of the Mann-Whitney test statistic: $408-412$.
DE JAGER, K. 1994. Obsolescence and stress: a study of the use of books on open shelves at a university library. Journal of librarianship and information science. 26(2):76-77.

DE JAGER, K. 1991. Whom do we serve? User perceptions in a South African university library. South African journal of library and information science, 59(4):276-281.

EVANS, G.E. 1970. Book selection and book collection usage in academic libraries. Library quarterly, 40(3):297-308.

FORD, G. 1990. Review of methods employed in determining the use of library stock. London: British National Bibliography Research Fund. (British National Bibliography Research Fund Report; 43).

HISCOCK, J.E. 1986. Does library usage affect academic performance? Australian academic and research libraries, 17(4):207213.

KNAPP, P.B. 1968. The reading of college students. Library quarterly, 38(4):301-308.

KRAMER L.A. \& KRAMER, M.B. 1968. The college library and the drop-out. College \& research libraries, 29(4):310-312.

LANE, G. 1966. Assessing the undergraduates' use of the university library. College \& research libraries, 27(4):277-282.

MAYS, T. 1986. Do undergraduates need their libraries? Australian academic and research libraries, 17(2):56-62.

MOSES, L.E. 1986. Think and explain with statistics. Reading, Mass.: Addison-Wesley.

RESEARCH SURVEYS. 1994. Project monograph: use of and needs in relation to UCT library. (Unpublished report).

SELF, J. 1987. Reserve readings and student grades : analysis of a case study. Library information research news, 9(1):29-40. 